\title{
DIVERSIDAD DEL SOTOBOSQUE Y RADIACIÓN SOLAR EN UN BOSQUE DE Pinus hartwegii Lindl. CON QUEMA PRESCRITA
}

\author{
UNDERGROWTH DIVERSITY AND SOLAR RADIATION IN A Pinus hartwegii Lindl. \\ FOREST WITH PRESCRIBED BURNING
}

\author{
Gloria Elena Islas Madrid', Dante Arturo Rodríguez Trejo y yedro Arturo Martínez Hernández²
}

\section{RESUMEN}

Los bosques de Pinus hartwegii son beneficiados cuando presentan regímenes de fuego apropiados; si esto no ocurre, el uso de quemas prescritas es una alternativa para corregirlos; por lo anterior es relevante el estudio de la ecología del fuego. En el caso particular del Distrito Federal, los bosques proveen de servicios ambientales a los habitantes de la zona sur. Por lo tanto, sobre una ladera del volcán Ajusco se establecieron tres parcelas con quema prescrita de baja intensidad (largo de llama $<1 \mathrm{~m}$, velocidad de propagación $<3 \mathrm{~m} \mathrm{~min}^{-1}$ ), y tres parcelas no quemadas, como testigo; en un diseño experimental completamente al azar (3.6 ha por parcela en promedio). Al año siguiente se obtuvieron datos del sotobosque para calcular la riqueza de especies, los índices de diversidad de Shannon-Wiener y de Simpson, así como los valores de importancia. Los análisis de varianza multivariados y univariados mostraron aumento de la riqueza y diversidad de especies en las parcelas quemadas. Muhlenbergia quadridentata aumentó su densidad y dominancia a mayor radiación, pero Penstemon gentianoides redujo esta última al incrementarse la radiación, lo cual puede relacionarse con una mayor humedad en sitios parcialmente sombreados. La diversidad se eleva por la disminución en la competencia con los zacates, que dominan las localidades no quemadas.

Palabras clave: Diversidad, efectos del fuego, Pinus hartwegii Lindl., quemas prescritas, radiación solar, riqueza de especies.

\section{ABSTRACT}

Pinus hartwegii forests are favored when they have the right fire regimes, but when this does not happen, the use of prescribed burnings is an option to correct them, which makes the study of fire ecology a relevant matter in this context. In the particular case of Distrito Federal, forests provide environmental services to the people who live at the southern part. Therefore, over a hillside of Ajusco volcano, three plots

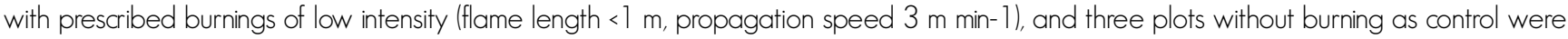
established at a completely random experimental design (3.6 ha per plot in average). A year later, data from the undergrowth were taken to determine species richness, Shannon-Wiener and Simpson diversity indexes as well as the importance values. The multivariate and univariate analyses of variance revealed an increment in the richness and diversity of species in the burned plots. Muhlenbergia quadridentata increased its density and dominance below greater radiation, but Penstemon gentianoides reduced the latter when radiation was higher, which might be related to a greater moisture in partially shadowed sites. Diversity becomes more important when competition with grasses gets lower, as they dominate the not-burned locations.

Key words: Diversity, fire effects, Pinus hartwegii Lindl., prescribed burns, solar radiation, species richness.

Fecha de recepción: 4 de abril de 2010

Fecha de aceptación: 17 de julio de 2012

\footnotetext{
'División de Ciencias Forestales, Universidad Autónoma Chapingo. Correo-e: zoeflakyła@gmail.com

2 Departamento de Zootecnia, Universidad Autónoma Chapingo.
} 


\section{INTRODUCCIÓN}

Pinus hartwegii Lindl. tiene una amplia distribución geográfica, que comprende Honduras, Guatemala y México, donde se ubica entre 2900 y más de 4000 msnm (Perry, 1991). En el sur y poniente del Distrito Federal forma bosques con otras especies de pino, encino y oyamel, los cuales suministran diversos servicios ambientales a los habitantes de la ciudad; por ejemplo, la provisión de agua, captura de carbono, generación de oxígeno, el mantenimiento de biodiversidad, recreación, entre otros, por lo que el gobierno local los incluye en sus programas de reforestación como una medida para contribuir a su conservación. Esta especie es importante económicamente pues, al ser maderable, se emplea en la construcción, carpintería, en la elaboración de tableros y postes de energía. Asimismo, sus bosques presentan un régimen de incendios frecuentes (3-15 años) y superficiales, por lo que tienen una serie de adaptaciones al fuego: regeneración en localidades incendiadas, cespitosidad, buena poda natural, recuperación del follaje afectado, corteza gruesa que aísla al cambium vascular de temperaturas letales, y en función de la población, capacidad de rebrote después de que la parte aérea fue dañada (Rodríguez, 1996; Rodríguez y Fulé, 2003; Rodríguez et al., 2004).

El Distrito Federal, pese a tener una superficie forestal de apenas 45000 ha, a menudo ocupa los primeros lugares, en número de incendios a nivel nacional, de los cuales aproximadamente la mitad se debe a causas agropecuarias, mas no en superficie afectada (Conafor, 2009; Gobierno de la Giudad de México, 2009).

No obstante las adaptaciones de esta especie a los incendios, los cambios en su régimen de fuego, tales como el aumento en la frecuencia e intensidad, pueden rebasar su resistencia y originar su mortalidad; de igual forma, la exclusión del fuego representa una considerable acumulación de combustible que puede ocasionar efectos devastadores con un incendio de intensidad extrema (Rodríguez, 2001).

El sur del Distrito Federal, lugar donde se desarrolló la investigación, está influido por distintos factores de disturbio, tales como, el sobrepastoreo y la alteración de los regímenes de fuego; en consecuencia, la zona adquiere una gran importancia ecológica, en particular, por los servicios ambientales que representa. Una opción para preservar regímenes de fuego adecuados y conservar estos ecosistemas es el uso de quemas prescritas. Para ello es necesario investigar los efectos del fuego con diferentes características (intensidad y época) en los componentes, estructuras y procesos ecosistémicos. La radiación solar tiene una importante influencia sobre la vegetación del sotobosque. La luz visible influye en el estado general de las plantas $y$, si es insuficiente, los tallos crecen excesivamente a expensas de las hojas, y el sistema radical se desarrolla poco (Lambers et al., 1998).

\section{INTRODUCTION}

Pinus hartwegii Lindl. has a wide geographic distribution which includes Honduras, Guatemala and México, between 2900 and over 4000 masl (Perry, 1991). At the south and west of Distrito Federal it forms forests with different pine, oak, and fir species, which provide several environmental services to the people of the city such as water, carbon sequestration, oxygen, biodiversity maintenance, recreation, among others, which is why the local government considers them in the reforestation programs as a strategy to keep their conservation. This species is economically important as it is woody and is used in building, carpentry, board and electric post production. Their communities exhibit a regime of frequent ( 3 to 15 years) and superficial fires, which have developed a series of adaptations to fire: regeneration in burned sites, initial grass-growth, good natural pruning, restoration of damaged foliage, thick bark that isolated the vascular cambium from lethal temperature, and, according to the population, ability of growing after the aerial part has been harmed (Rodríguez, 1996; Rodríguez and Fulé, 2003; Rodríguez et al., 2004).

Distrito Federal, in spite of its small area, 45000 ha, frequently stands as the first place in the number of fires, at a national scale, around half of which are due to agriculture and livestock activities, but not in terms of the affected area (Conafor, 2009; Gobierno de la Ciudad de México, 2009).

Even if this species has adapted to fires, changes in their regime such as increment in frequency and intensity might surpass their resistance and cause their death; on the other hand, fire means a great fuel accumulation that might have catastrophic effects if a forest fire of great intensity takes place (Rodríguez, 2001).

Southern Distrito Federal, where the actual research project was carried out, is influenced by several disturb factors such as overgrazing and the modification of fire regimes; consequently, the zone becomes of great ecological importance as well as for the environmental services it provides. One option to preserve the right fire regimes and preserve these ecosystems is the use of prescribed burnings. Therefore, it is necessary to investigate the effects of fire with different characteristics (intensity and station) of the elements, structures and ecosystem processes. Solar radiation has an important influence upon undergrowth. Visible light influences the general state of plants and, if it is not enough, stems grow excessively in regard to leaves, and the root system has a poor development (Lambers et al., 1998).

There are a few studies that combine the effects of fire and solar radiation over undergrowth; however, they indicate that there is a relation among space opening, the consequence of fire and the diversity of species in the undergrowth due to higher radiation levels, which favor the presence of species that demand them (Spencer and Baxter, 2006). This is one of the reasons why fire is fundamental for the continuation of diverse kinds of ecosystems 
Existen pocos estudios que combinan los efectos del fuego y la radiación solar sobre el sotobosque; sin embargo, estos indican que hay relación entre la apertura de espacio, la consecuencia del fuego y la diversidad de especies del sotobosque debido a los mayores niveles de radiación, los cuales favorecen la presencia de especies que los requieren (Spencer y Baxter, 2006). Esta es una de las razones por las que el fuego es fundamental para la continuidad de diversos tipos de ecosistemas, y acorde con Shlisky et al. (2007) en algunos países, principalmente en los Estados Unidos de América, se utiliza como una herramienta de manejo de los recursos naturales.

Los objetivos de la presente investigación fueron determinar la diversidad y riqueza de los estratos herbáceo y arbustivo del sotobosque de Pinus hartwegii, después de aplicar quemas prescritas de baja intensidad en bosques adultos, y estudiar la relación de la densidad y dominancia de las principales especies del sotobosque con los distintos niveles de cobertura de copas.

Se plantea como hipótesis que la diversidad y riqueza de especies en los estratos herbáceo y arbustivo aumentarán con la quema prescrita; además, la apertura ligera de copas, resultado del tratamiento con fuego, permitirá el paso de más radiación. La quema también reducirá la competencia con zacates y todo ello favorecerá la presencia de taxa tolerantes al fuego.

\section{MATERIALES Y MÉTODOS}

El área de estudio se ubicó en el Parque Nacional Cumbres del Ajusco, sobre la ladera oeste del volcán homónimo, al sur del Distrito Federal. Sus coordenadas geográficas son 99 16'23" latitud norte y $19^{\circ} 12^{\prime 2} 29^{\prime \prime}$ longitud oeste, y su clima es C(E) ( $\left.w_{2}\right)$ : templado subhúmedo, el más húmedo de los subhúmedos, con lluvias en verano (García, 1973); temperatura media anual entre 5 y $12{ }^{\circ} \mathrm{C}$, precipitación media anual de $1138.62 \mathrm{~mm}$ y altitud de $3475 \mathrm{~m}$.

El experimento se estableció en un bosque de Pinus hartwegii y consistió en la aplicación de quema prescrita a baja intensidad y la no aplicación de esta (testigo). La investigación se dispuso en una superficie total de 21.6 ha, donde se delimitaron, al azar, seis parcelas de forma rectangular con un promedio de 3.6 ha cada una. En tres de ellas se empleó la quema prescrita, que fue dirigida y realizada por personal de la Universidad Autónoma Chapingo, del Gobierno del D.F. y de la Comisión Nacional Forestal. Las quemas prescritas a baja intensidad, en fajas en contra del viento y pendiente, aprobadas por las dos últimas instituciones, así como por la comunidades de San Miguel y de Santo Tomás Ajusco, poseedoras de esas tierras, se efectuaron del 14 al 20 de marzo de 2006 en las primeras horas de la mañana. Durante el proceso se registraron temperaturas de 7.8 a $15.5^{\circ} \mathrm{C}$, humedades relativas de 30 a $50 \%$ y velocidades de viento de $\mathrm{O}$ a $12 \mathrm{~km} \mathrm{~h}^{-1}$. El fuego alcanzó una velocidad de propagación menor a $3 \mathrm{~m} \mathrm{~min}^{-1}$ y un largo de llama inferior a $1 \mathrm{~m}$ and, according to Shlisky et al. (2007) in some countries, mainly in the United States of America, it is used as a tool to manage natural resources.

The objectives of the actual research were to determine the diversity and richness of species of the herb and shrub strata of the undergrowth of Pinus hartwegii, after applying prescribed burnings of low intensity in adult forests and to study the relation of the density and dominance of the main species of the undergrowth with the different levels of crown covers.

It is stated as an hypothesis that the diversity and richness of species in the herb and shrub strata will increase from prescribed burning; in addition, the light opening of canopies, as a result of the treatment with fire, will let a greater radiation input. Burning will also reduce the competence with grasses and all of it will favor the presence of taxa that are tolerant to fire.

\section{MATERIALS AND METHODS}

The study area was located in the Cumbres del Ajusco National Park, over the west hill of the volcano with the same name at western Distrito Federal. Its geographic coordinates are 99 16'23" North and 19 12'29" West, and its weather formula is C(E) $\left(w_{2}\right)$ : subhumid mild, the most humid of the subhumids, with summer rains (García, 1973); annual mean temperature between 5 and $12^{\circ} \mathrm{C}$, annual mean rainfall of $1138.62 \mathrm{~mm}$ and $3475 \mathrm{~m}$ asl.

The experiment was established in a Pinus hartwegii forest and consisted in an application of low intensity prescribed burning and the not-application of it as control. The research project was displayed in a total area of $21.6 \mathrm{ha}$, where six rectangular plots were marked at random, with an average area of 3.6 ha each. In three of them was used prescribed burning, that was directed and made by workers of the Universidad Autónoma Chapingo, of the Gobierno del D.F. and of the Comisión Nacional Forestal. The prescribed burning at low intensity, in strips against the wind and slope, and approved by the two latter organizations as well as by San Miguel and Santo Tomás Ajusco communities were made from 14 to 20 march of 2006 in the first hours of the morning. During the process, temperatures of 7.8 to $15.5^{\circ} \mathrm{C}$, relative humidity of 30 to $50 \%$ and wind speeds of 0 to $12 \mathrm{~km} \mathrm{~h}^{-1}$ took place. Fire reached a propagation speed below $3 \mathrm{~m} \mathrm{~min}^{-1}$ and a flame length below $1 \mathrm{~m}$ (once, it even reached $3 \mathrm{~m}$ ) (Figure 1). The experimental design was completely at random with three replications. In each plot were located observation stations with the following tree canopy openings: open, semi-open and closed.

For the prescribed burning treatment a total of 48 observation stations: 24 for the herb stratum and 24 for the shrub stratum, while for control, 12 in each one of them. All the stations were made up by sampling sites for herbs $(1 \times 1 \mathrm{~m})$ and shrubs $(4 \times 4 \mathrm{~m})$ and the first located inside the second ones. 
(en una ocasión alcanzó 3 m) (Figura 1). El diseño experimental fue completamente al azar, con tres repeticiones. En cada parcela se situaron estaciones de observación con las siguientes coberturas de dosel arbóreo: abierta, semiabierta y cerrada.

Para el tratamiento de quema prescrita se delimitaron un total de 48 estaciones de observación: 24 para el estrato herbáceo y 24 para el arbustivo; mientras que para el testigo 12 en cada uno de ellos. Todas las estaciones se conformaron por sitios de muestreo para hierbas $(1 \times 1 \mathrm{~m})$ y $\operatorname{arbustos}(4 \times 4 \mathrm{~m})$, los primeros ubicados dentro de los segundos.
Individuals by species were counted and cover was determined as per cent in herbs and by measuring crowns in shrubs. The number of species was recorded too.

Botanic examples were collected for their later identification at the Herbarium of the Zootechny Department of the Universidad Autónoma Chapingo. This sampling was carried out in October 2007, at the end of the rain season, a year and a half after the application of prescribed burning, and the flowering stage of most of the components of the undergrowth is taking place. With the previous information were calculated the diversity indexes of Shannon-Wiener, of Simpson, the per cent of the importance value (Krebs, 1985).
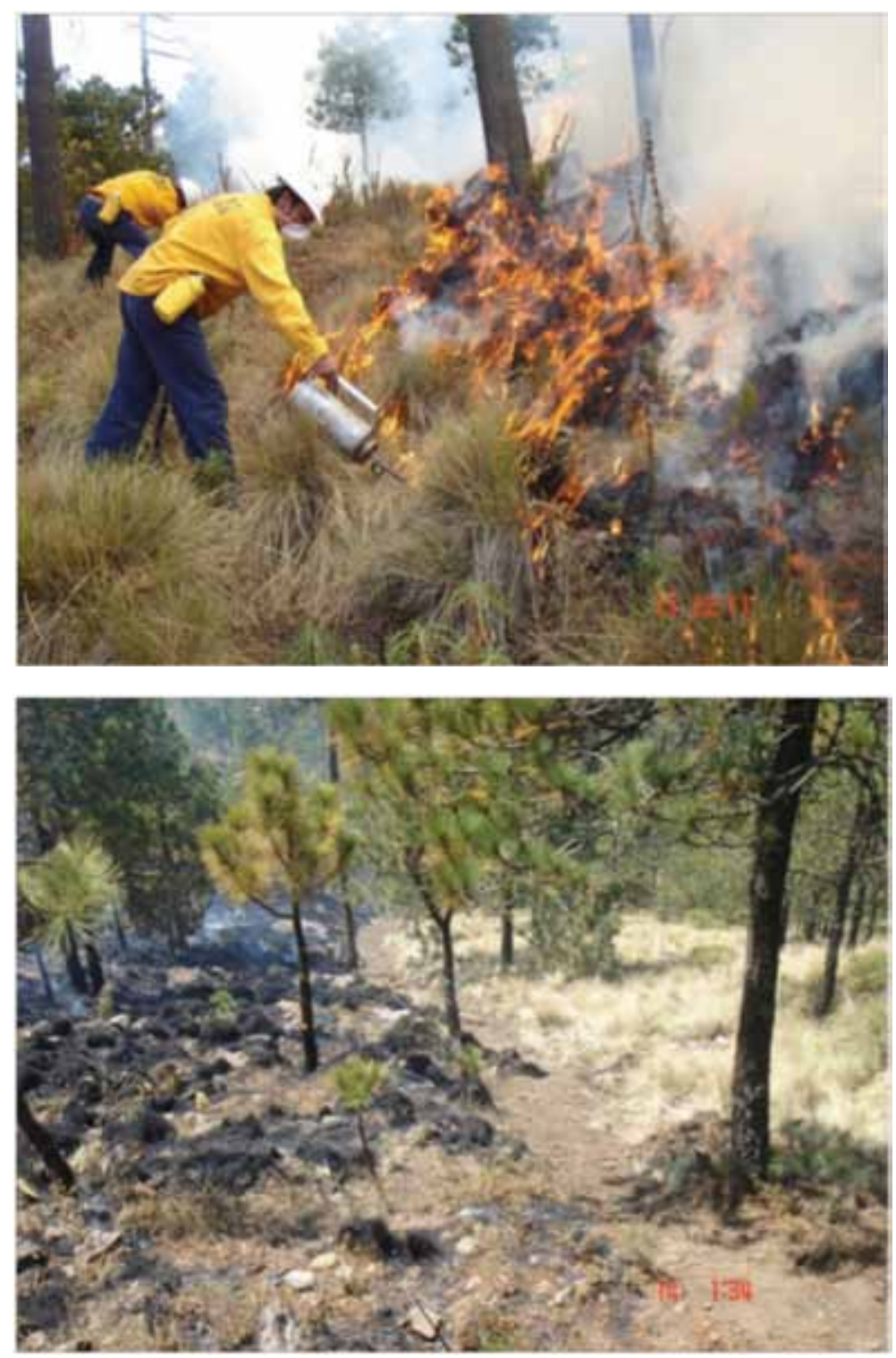

Figura 1. Quema prescrita en curso en el área de estudio (arriba). Vista de un área tratada limítrofe con otra no tratada (abajo).

Figure 1. Prescribed burning underway in the study area (up). View of the limiting treated area against another not treated (down). 
Se contaron los individuos por especie y se determinó la cobertura: porcentualmente en herbáceas y se midieron las copas en las arbustivas. Asimismo, se registró el número de especies.

Se colectaron ejemplares botánicos para su posterior identificación en el Herbario del Departamento de Zootecnia de la Universidad Autónoma Chapingo. Este muestreo se efectuó durante octubre de 2007, a finales de la temporada de lluvias, año y medio después de la aplicación de la quema prescrita, época de floración de la mayoría de los componentes del sotobosque. Con la información anterior se calcularon los índices de diversidad de Shannon-Wiener, de Simpson, el valor de importancia y el porcentaje del valor de importancia (Krebs, 1985).

La cuantificación de la radiación solar recibida bajo dosel se realizó a través de la toma de fotos digitales desde el piso hacia el zenith, con una cámara de lente hemisférica, nivelada y orientada al norte (Figura 2).

Las radiaciones solares difusa, directa y total, todas bajo dosel, así como la porción de cielo visible se obtuvieron por medio del suministro de coordenadas geográficas, altitud y día juliano al programa Hemiview ${ }^{\circledR}$ (Figura 3).

Se llevó a cabo un análisis de varianza multivariado para los dos índices de diversidad y la riqueza de especies. El modelo con un criterio de clasificación para " $p$ " respuestas fue el siguiente:

$$
\begin{gathered}
y_{i j}=\mu+T_{i}+\varepsilon_{i j} \\
(p x l)(p x l)(p x l)(p x l)
\end{gathered}
$$

Donde:

$$
\begin{aligned}
y_{i j}= & \text { Vector de respuestas en la j-ésima repetición con el } \\
& \text { i-ésimo tratamiento } \\
\mu= & \text { Vector de medias general } \\
T_{i}= & \text { Vector de efectos del i-ésimo tratamiento } \\
\varepsilon_{i i}= & \text { Vector de errores aleatorios, con } N_{p}(0, \Sigma) \\
i= & 1,2 \\
i= & 1,2,3
\end{aligned}
$$

Se examinó cada parámetro de manera individual, mediante el análisis de varianza y prueba de comparación de medias de Tukey. El modelo utilizado fue:

$$
y_{i j}=\mu+\alpha_{i}+\varepsilon_{i j}
$$

Donde:

$$
\begin{aligned}
y_{i i}= & \text { Respuesta de la i-ésima repetición con el i-ésimo } \\
& \text { nivel del tratamiento fuego }
\end{aligned}
$$

$\mu=$ Media general

$\boldsymbol{\alpha}_{i}=$ Efecto del i-ésimo nivel del tratamiento fuego

$\boldsymbol{\varepsilon}_{i j}=$ Error experimental

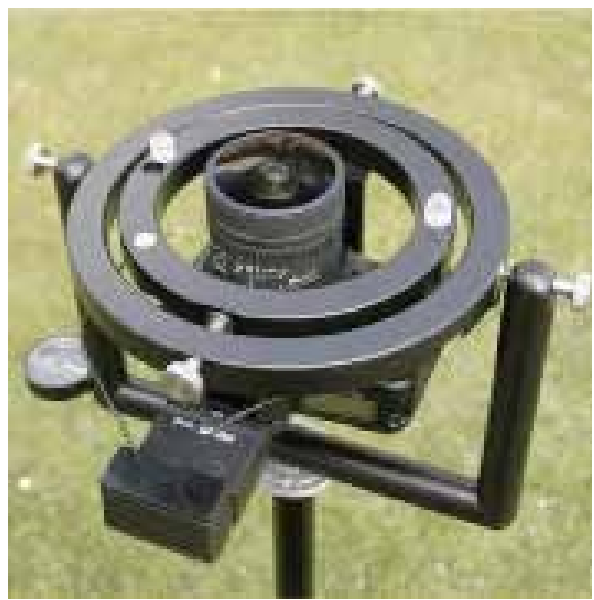

Figura 2. Cámara digital, lente hemisférica y soporte con estructura niveladora.

Figure 2. Digital hemispheric lens and support with leveling structure.

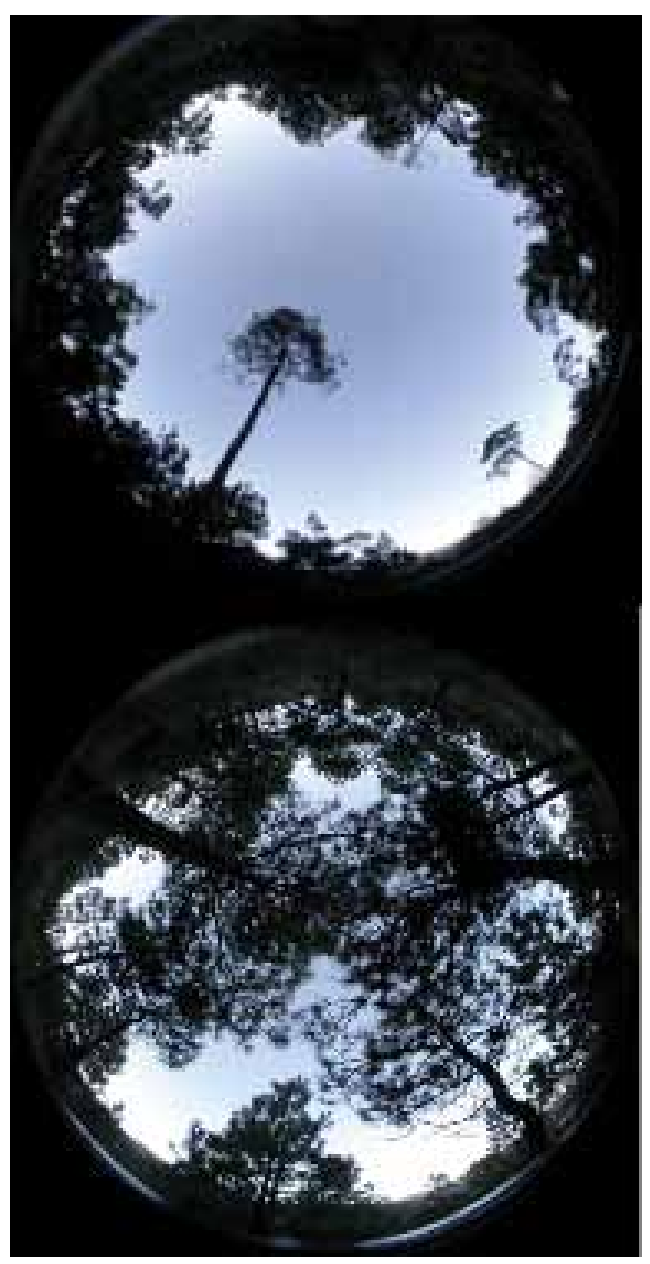

Figura 3. Ejemplos de fotos hemisféricas en sitio abierto (arriba) y en sitio cerrado (abajo).

Figure 3. Hemispheric photos in an open place (up) and a closed place (down). 
Para las especies con mayor valor de importancia se aplicó una prueba de $\chi^{2}$, a fin de determinar las especies típicas, es decir, aquellas con mayor frecuencia en el tratamiento de quema prescrita o en el testigo. Los análisis se efectuaron con los procedimientos procmanova, procglm y procfreq leste último para el análisis no paramétrico) del programa Statistical Analysis System (SAS, 1999) versión 8.0, para microcomputadoras.

\section{RESULTADOS Y DISCUSIÓN}

\section{Radiación solar}

Las radiaciones solar difusa, directa y total, todas bajo dosel, son equivalentes en las parcelas con quema prescrita y en las parcelas sin quema, pues no se obtuvieron diferencias estadísticamente significativas entre ellas ( $p<0.05)$. Lo anterior indica que al año de emplear el fuego prescrito, la poca afectación que pudo existir en el follaje de los árboles prácticamente desapareció; sólo en la porción de cielo visible se detectaron diferencias con $\mathrm{p}<0.10$ (Cuadro 1).

Cuadro 1. Medias de cielo visible y radiaciones solares bajo dosel. Table 1. Mean values of visible sky and solar radiations below the canopy.
RDF

( $\left.M J \mathrm{~m}^{-2} \mathrm{año}^{-1}\right)$
The quantification of solar radiation that is received below the canopy was made through digital photographs from the floor to the zenith, with a hemispheric lens camera, leveled and oriented to the north (Figure 2).

The total, direct and diffuse solar radiations, all of them below the canopy, as well as the visible sky portion were obtained by means of the geographic coordinates, altitude and Julian day to the Hemiview ${ }^{\circledast}$ (Figure 3).

A multivariate analysis of variance was made for the two diversity indexes and the richness of species. The model with a classification criterion for " $p$ " responses was the following:

$$
\begin{gathered}
y_{i j}=\mu+T_{i}+\varepsilon_{i j} \\
(p x \mid)(p x \mid)(p x \mid)(p x \mid)
\end{gathered}
$$

CV

$(\%)$

\begin{tabular}{|c|c|c|}
\hline$Q P$ & $45.3 a$ & $601.7 a$ \\
\hline QNP & & \\
\hline \multicolumn{3}{|c|}{$\begin{array}{l}\text { Las medias en hileras con la misma letra denotan que no hay differencias estadistit } \\
\mathrm{CV}=\text { Coeficiente de variación; RDF = radiación solar difusa; RT = radiación total; } \\
\text { The means in rows with the same letter denote that there are non- significant diffe } \\
\mathrm{CV}=\text { Coefficient of variation; } \mathrm{RDF} \text { = diffuse solar radiation; } \mathrm{RT} \text { = total radiation; }\end{array}$} \\
\hline \multicolumn{3}{|c|}{$\begin{array}{l}\text { Se identificaron } 30 \text { especies en el sotobosque dentro de los } \\
\text { sitios de muestreo en ambas áreas (Cuadro 2): } 25 \text { herbáceas y cinco } \\
\text { arbustivas; mientras que en las áreas testigo se reconocieron } 15 \text {. }\end{array}$} \\
\hline \multicolumn{3}{|c|}{$\begin{array}{l}\text { Con base en el análisis multivariado para la riqueza de } \\
\text { especies y los dos indicadores de diversidad se observaron } \\
\text { diferencias significativas entre los tratamientos, de acuerdo } \\
\text { con los siguientes cuatro estadísticos: Raíz más grande de Roy, } \\
\text { Wilk's Lambda, Pillai's Trace y Hotelling-Lawley Trace (todos con } \\
\text { p<0.01 para el caso de herbáceas y p<0.10 para arbustivas). }\end{array}$} \\
\hline
\end{tabular}

Tratamiento

Mediante el análisis de varianza se advirtieron diferencias significativas para el índice de diversidad de Shannon-Wiener en herbáceas entre las dos condiciones $(\mathrm{p}=0.0036)$, con medias de 2.18 y 1.61 para áreas quemadas y no quemadas, respectivamente. La misma diferencia ( $p=0.0142$ ) se distinguió para el índice de Simpson, con medias de 0.72 en áreas con quema y 0.59 en las testigo. En el caso de las especies arbustivas no hubieron diferencias $(p=0.9500$ ) en el índice de Shannon-Wiener entre áreas quemadas (1.03) y no quemadas (1.02); lo mismo ocurrió con el índice de Simpson (p=0.8105), con valores de 0.42 en los sitios con quema y 0.40 en los testigo.

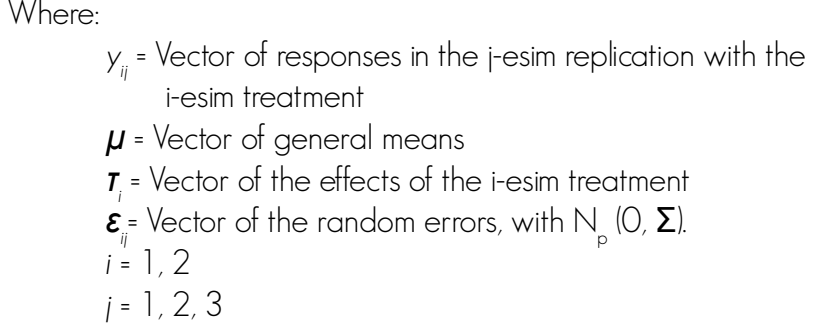

Each parameter was examined individually, by an analysis of variance and Tukey's mean comparison test. This was the model that was used:

$$
y_{i j}=\mu+\alpha_{i}+\varepsilon_{i j}
$$

Where:

$y_{i i}=$ Response of the i-esim replication with the i-esim level of the fire treatment

$\mu=$ General mean

$\boldsymbol{\alpha}=$ Efect of the i-esim level of the fire treatment.

$\varepsilon_{i j}=$ Experimental error 
Cuadro 2. Listado florístico.

Table 2. Floristic list.

\begin{tabular}{|c|c|}
\hline Especies & Familia \\
\hline \multicolumn{2}{|l|}{ Herbáceas } \\
\hline Alchemilla procumbens Rose & Rosaceae \\
\hline Agrostis tolucensis Kunth & Poaceae \\
\hline Astragalus micranthus Desv. & Leguminosae \\
\hline Calamagrostis tolucensis (Kunth) Trin. ex Steud. & Poaceae \\
\hline Cerastium brachypodum (Engelm. ex A. Gray) B.L. Rob. & Caryophyllaceae \\
\hline Erigeron galeottii (A. Gray) Greene & Asteraceae \\
\hline Eupatorium oligocephalum DC. & Asteraceae \\
\hline Festuca tolucensis Kunth & Poaceae \\
\hline Gnaphalium inornatum DC. & Asteraceae \\
\hline Gnaphalium sphacilathum DC. & Asteraceae \\
\hline Malaxis ehrenbergii (Rchb. f.) Kuntze & Orchidaceae \\
\hline Muhlenbergia quadridentata $\bigcirc$. (Kunth) Trin. & Poaceae \\
\hline Penstemon gentianoides (Kunth)Poir. & Scrophulariaceae \\
\hline Peperomia campylotropa A.W. Hill. & Piperaceae \\
\hline Pernettya ciliata Small & Ericaceae \\
\hline Potentilla ranunculoides Kunth & Rosaceae \\
\hline Rumex mexicanus Meisn. & Polygonaceae \\
\hline Salvia prunelloides Kunth & Laminaceae \\
\hline Selloa plantaginea Kunth & Asteraceae \\
\hline \multicolumn{2}{|l|}{ Arbustos } \\
\hline Senecio angulifolius DC. & Asteraceae \\
\hline Senecio callosus Sch. Bip. & Asteraceae \\
\hline Viola humilis Kunth & Violaceae \\
\hline Senecio sanguisorbae DC. & Asteraceae \\
\hline Senecio toluccanus DC. & Asteraceae \\
\hline Lupinus montanus Kunth & Leguminosae \\
\hline Eryngium monocephalum Cav. & Apiaceae \\
\hline Senecio cineraroides Kunth & Asteraceae \\
\hline Cirsium ehrenbergii Sch. Bip. & Asteraceae \\
\hline Baccharis conferta Kunth & Asteraceae \\
\hline Senecio reticulatus DC. & Asteraceae \\
\hline
\end{tabular}

En el presente trabajo se registró 33\% adicional de especies en el sotobosque dentro de las parcelas con quemas prescritas, en comparación con las 20 referidas por Martínez y Rodríguez (2008)
For the species with a higher importance value a $\chi^{2}$ test was applied in order to determine the most typical species, that is, those that appear more frequently in the prescribed burning treatment or 
en masas abiertas y más jóvenes de Pinus hartwegii localizadas en sitios con $150 \mathrm{~m}$ más de altitud y exposición $\mathrm{NO}$ en el mismo volcán Ajusco. Entre otros factores, esto puede obedecer a que al incrementarse la altitud, la riqueza y diversidad de especies decrecen a causa de las bajas temperaturas (Krebs, 1985).

Conforme a Wright y Bailey (1982) y Whelan (1997), la mayor diversidad superior en muchas áreas afectadas por el fuego responde al aumento de radiación durante los primeros meses posteriores, así como al aumento en la disponibilidad de nutrientes, por la presencia de las cenizas derivadas de la combustión, y la reducción de competencia con zacates. Todos ellos son factores que también propician la floración de las especies, como lo han notado Benítez (1987) para Muhlenbergia macroura (Kunth) Hitch.) y Festuca tolucensis Kunth en la misma zona y Martínez y Rodríguez (2008) y Espinoza et al. (2008) para diversas especies dicotiledóneas. Entre los ecosistemas mantenidos por el fuego, donde este incrementa la diversidad, están los de Pinus palustris Mill. al sur de los Estados Unidos de América y los de P. ponderosa Douglas ex P. Lawson \& C. Lawson al oeste de dicho país (Wade et al., 2000; Agee, 1993). En este último caso, los incendios forestales tienen poco efecto en el estrato herbáceo, ya que las especies con bulbos y tubérculos rara vez son dañadas por el fuego (Agee, 1993).

Brockway y Lewis (1997) analizaron los efectos a largo plazo de varias quemas prescritas en la diversidad y productividad de un ecosistema de $P$. palustris; y obtuvieron un aumento en la diversidad y uniformidad de la vegetación tanto en herbácea, como en arbustiva $y$, por tanto, un incremento en la productividad de su biomasa. Los mejores resultados se lograron a dos años de la quema prescrita. En las mismas parcelas del Ajusco utilizadas para este trabajo se tiene una supervivencia del arbolado con $>1 \mathrm{~cm}$ de diámetro normal igual a $86 \%$.

\section{Valor de importancia}

Ninguna especie domina entre las herbáceas en el área quemada con prescripción, solo existe] una reducción pequeña y gradual si se ordenan en forma descendente (Cuadro 3). Festuca tolucensis y Penstemon gentianoides (Kunth) Poir. tuvieron los mayores valores; en tanto que, en el estrato arbustivo domina Lupinus montanus Kunth, con más de un tercio del porcentaje de valor de importancia (Cuadro 4).

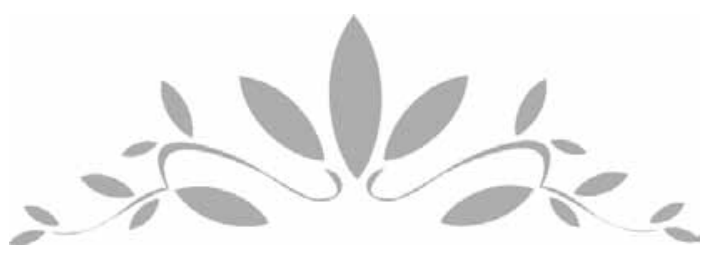

in the control. Analyses were made with the procmanova, procglm and procfrea procedures (the latter for the non parametric analysis) of the 8.0 version of the SAS program (SAS, 1999).

\section{RESULTS AND DISCUSSION}

\section{Solar radiation}

Diffuse, direct and total solar radiations, all below the canopy, are equivalent in themselves in the plots with prescribed burning and in plots without burning, as there were statistically non significant differences among them $(p<0.05)$. This means that after one year of having used prescribed fire, the light damages that could have existed in the foliage of the trees almost disappeared; just in the portion of visible sky were detected differences with (Table 1).

Thirty species were identified in the undergrowth within the sampling sites in both areas (Table 2): 25 herbs and five shrubs, while in control areas, 15 were found.

Based upon the multivariate analysis for species richness and the two diversity indicators, significant differences were observed among treatments, according to the following four statistics: Roy's largest root test, Wilk's Lambda, Pillai's Trace and Hotelling-Lawley Trace lall with $\mathrm{p}<0.01$ for herbs and $\mathrm{p}<0.10$ for shrubs).

Through the analysis of variance were detected significant differences for the Shannon-Wiener diversity index in shrubs below both situations ( $p=0.0036$ ), with medias of 2.18 and 1.61 for burned and not-burned areas, respectively. The same difference ( $p=0.0142$ ) was determined for the Simpson index, with means of 0.72 in areas with burnings and 0.59 in those of control. In shrub species there were no differences ( $p=0.9500$ ) in the Shannon-Wiener index between burned (1.03) and not-burned (1.02) areas; the same thing happened with the Simpson index ( $p=0.8105$ ), with values of 0.42 in burned sites and 0.40 in control places.

In the actual study, an additional $33 \%$ of the species in the undergrowth within the prescribed burning plots was registered, compared to 20 referred by Martínez and Rodríguez (2008) in Pinus hartwegii open and younger masses located in places $150 \mathrm{~m}$ asl higher at NW hillsides in the same Ajusco volcano. Among other factors, this might be due to the fact that as altitude becomes higher, species richness and diversity decrease from low temperatures (Krebs, 1985).

According to Wright and Bailey (1982) and Whelan (1997), the greatest diversity areas affected by fire react to the increment of radiation during the first months after the event, as well as to a better availability of nutrients due to the presence of ashes that come from combustion and a lower competence with grass. All of these factors also promote the flowering of species, as it has been noted by Benítez (1987) for Muhlenbergia macroura (Kunth) Hitch.) and Festuca tolucensis Kunth in the same zone 
Cuadro 3. Porcentaje de valor de importancia en especies del estrato herbáceo de las parcelas con quema.

Table 3. Importance value per cent in species of the herb stratum of burned plots.

\begin{tabular}{|c|c|}
\hline Especie & $\begin{array}{c}\text { Valor de importancia } \\
(\%)\end{array}$ \\
\hline Festuca tolucensis Kunth & 11.15 \\
\hline Penstemon gentianoides (Kunth) Poir. & 10.39 \\
\hline $\begin{array}{l}\text { Calamagrostis tolucensis (Kunth) Trin. } \\
\text { ex Steud. }\end{array}$ & 9.36 \\
\hline $\begin{array}{l}\text { Muhlenbergia quadridentata } \bigcirc \text {. } \\
\text { (Kunth) Trin. }\end{array}$ & 9.22 \\
\hline Selloa plantaginea Kunth & 7.97 \\
\hline Alchemilla procumbens Rose & 7.53 \\
\hline Viola humilis Kunth & 7.53 \\
\hline Salvia prunelloides Kunth & 6.79 \\
\hline Gnaphalium sphacilathum DC. & 5.33 \\
\hline Senecio angulifolius DC. & 5.05 \\
\hline Senecio callosus Sch. Bip. & 3.92 \\
\hline Astragalus micranthus Desv. & 3.53 \\
\hline Senecio toluccanus DC. & 2.96 \\
\hline Erigeron galeottii (A. Gray) Greene & 2.72 \\
\hline Senecio reticulatus DC. & 2.44 \\
\hline $\begin{array}{l}\text { Cerastium brachypodum (Engelm. } \\
\text { ex A. Gray) B.L. Rob. }\end{array}$ & 2.27 \\
\hline Senecio sanguisorbae DC. & 2.15 \\
\hline Pernettya ciliata Small & 1.84 \\
\hline Peperomia campylotropa A.W. Hill & 1.53 \\
\hline Potentilla ranunculoides Kunth & 1.00 \\
\hline Eupatorium oligocephalum DC. & 0.58 \\
\hline Gnaphalium inornatum DC. & 0.54 \\
\hline $\begin{array}{l}\text { Malaxis ehrenbergii (Rchb. f.) } \\
\text { Kuntze }\end{array}$ & 0.49 \\
\hline Rumex mexicanus Meisn. & 0.41 \\
\hline
\end{tabular}

En las áreas testigo, las herbáceas dominantes fueron Calamagrostis tolucensis (Kunth) Trin. ex Steud., Festuca tolucensis y Agrostis tolucensis Kunth, entre las tres acumulan más de 50\% del valor de importancia para el estrato. Tres arbustivas dominan con valores muy semejantes: Senecio cinerarioides Kunth., Cirsium ehrenbergii Sch. Bip. y Lupinus montanus (cuadros 5 y 6).
Cuadro 4. Porcentaje de valor de importancia, arbustivas, parcelas con quema.

Table 4. Importance value per cent in species of the shrub stratum of burned plots.

\begin{tabular}{lc}
\hline Especie & $\begin{array}{c}\text { Valor de importancia } \\
(\%)\end{array}$ \\
\hline Lupinus montanus Kunth & 34.75 \\
Eryngium monocephalum Cav. & 25.82 \\
Senecio cineraroides Kunth & 24.53 \\
Cirsium ehrenbergii Sch. Bip. & 10.74 \\
Baccharis conferta Kunth & 4.16 \\
\hline
\end{tabular}

and by Martínez and Rodríguez (2008) and by Espinoza et al. (2008) for different dicotyledones. Among the fire-dependent ecosystems where it increases diversity, are the Pinus palustris Mill. forests at south of the United States and the P. ponderosa Douglas ex P. Lawson \& C. Lawson located at the west of that nation (Wade et al., 2000; Agee, 1993); in the latter, forest fires have a light effect on the herb stratum sin species with bulbs and tubercles are rarely damaged by fires (Agee, 1993).

Brockway and Lewis (1997) analyzed the long lasting effects of several prescribed burnings on diversity and ecosystem productivity in a P. palustris ecosystems and obtained an increment in the diversity and uniformity of the herb and shrub vegetation, and therefore, an increment in the biomass productivity. The best results were accomplished after two years from the prescribed burning. In the same plots of Ajusco that were used for this study, there is $a>1 \mathrm{~cm}$ DAP tree survival of $86 \%$.

Importance value

A single species does not dominate the herbs in the prescribed burned area; there is only one small and gradual reduction if they are listed descendently (Table 3). Festuca tolucensis and Penstemon gentianoides (Kunth) Poir. had the highest values, while in the shrubs, Lupinus montanus Kunth is dominant with more than a third part of the importance value per cent (Table 4).

In control areas, the dominant herbs were Calamagrostis tolucensis (Kunth) Trin. ex Steud, Festuca tolucensis and Agrostis tolucensis Kunth, that as a whole make up 50\% of the importance value for the stratum. Three shrubs dominate with very similar values: Senecio cinerarioides Kunth., Cirsium ehrenbergii Sch. Bip. and Lupinus montanus (tables 5 and 6 ).

From the $\chi^{2}$ test, the species form Tables 7 and 8 belong to burned areas, while Malaxis ehrenbergii (Rchb. f.) $O$. Kuntze belong to non-affected areas, with a significance of 0.0896 . 
Cuadro 5. Porcentaje de valor de importancia, herbáceas, parcelas sin quema.

Table 5. Importance value per cent in species of the herb stratum of non- burned plots.

\begin{tabular}{lc}
\hline Especie & $\begin{array}{c}\text { Valor de } \\
\text { importancia } \\
(\%)\end{array}$ \\
\hline Calamagrostis tolucensis (Kunth) Trin. ex Steud. & 21.91 \\
Festuca tolucensis Kunth & 18.56 \\
Agrostis tolucensis Kunth & 13.25 \\
Cerastium brachypodum (Engelm. ex A. & 7.19 \\
Gray) B.L. Rob. & 7.09 \\
Pernettya ciliata Small & 6.77 \\
Gnaphalium sphacelatum Kunth & 5.31 \\
Peperomia campylotropa A.W. Hill. & 4.01 \\
Muhlenbergia quadridentata O. (Kunth) Trin. & 3.37 \\
Salvia prunelloides Kunth & 3.23 \\
Malaxis ehrenbergii (Rchb. f.) Kuntze & 2.88 \\
Erigeron galeottii (A. Gray) Greene & 2.78 \\
Senecio callosus Sch. Bip. & 2.18 \\
Senecio reticulatus DC. & 1.47 \\
Selloa plantaginea Kunth &
\end{tabular}

Cuadro 6. Porcentaje de valor de importancia, arbustivas, parcelas sin quema.

Table 6. Importance value per cent in species of the shrub stratum of non- burned plots.

\begin{tabular}{lc}
\hline Especie & $\begin{array}{c}\text { Valor de importancia } \\
(\%)\end{array}$ \\
\hline Senecio cineraroides Kunth & 27.72 \\
Cirsium ehrenbergii Sch. Bip & 27.31 \\
Lupinus montanus Kunth & 25.30 \\
Senecio angulifolius DC. & 13.96 \\
Baccharis conferta Kunth & 5.71 \\
\hline
\end{tabular}

A partir de la prueba de $\mathbf{X}^{2}$, las especies de los cuadros 7 y 8 son propias de áreas quemadas; mientras que Malaxis ehrenbergii (Rchb. f.) $\bigcirc$. Kuntze corresponde a las áreas no siniestradas, con una significancia de 0.0896 . M. ehrenbergii es considerada típica de sitios muy húmedos y sombríos del bosque de oyamel (Benitez, 1986). Las especies marcadas con asterisco en los cuadros 7 y 8 se citan por primera vez como típicas de áreas incendiadas en este ecosistema (Espinoza et al., 2008; Martínez y Rodríguez, 2008). En el caso de las arbustivas, las típicas de áreas quemadas resultaron ser Baccharis conferta, Lupinus montanus y Senecio cineraroides.
M. ehrenbergii grows in moist and umber fir forests (Benítez, 1986). The species with asterisk in tables 7 and 8 are quoted for the first time as proper to burned places in this ecosystem (Espinoza et al., 2008; Martínez and Rodríguez, 2008). In the case of shrubs, the typical burned areas are Baccharis conferta, Lupinus montanus and Senecio cineraroides.

Lupinus montanus and Penstemon gentianoides have been highlighted as indicators of burned areas (Rzedowski, 1978; Rodríguez and Sierra, 1992; García, 2004; Espinoza et al., 2008; Martínez and Rodríguez, 2008). Lupinus seed has a physical dormancy, and fire acts as a natural scarification agent that weakens the seed coat of the seeds that are slightly buried in the forest floor, which favors germination. The very deeply buried seeds do not get enough heat and those that are over the surface become charred (Acosta and Rodríguez, 2005; Martínez et al., 2008).

As in this case, Armour et al. (1984) described indicator species in burned areas in Pinus ponderosa forests, even for different fire intensities: Berberis repens Lindl. was absent in high intensity places; Luzula campestris (L.) DC. was seven times more frequent in not-affected spaces than in those burned at high intensity; Fragaria virginiana Mill. was present twice in zones without fire and burned at low intensity, compared to those of high intensity; Potentilla gracilis Douglas ex Hook., Geum triflorum Pursh. and Vicia americana Muhl. ex Willd. were more regularly found in low intensity areas than in others; Ceanothus sanguineus Pursh. and Apocynum androsaemifolium L. were only recorded in high intensity places; Epilobium angustifolium L. was twice to five times more frequent in high intensity spaces than in those of low values, and extremely rare in not-burned zones; Collomia linearis Nutt. was located in burned and not-burned areas, but was more common in those of high intensity.

\section{Solar radiation effects}

Only three of all of the herb species found in the plots with prescribed burnings showed significant tendencies. The regressions with $\mathrm{R}^{2}>0.4$ and with $p<0.10$ were taken into account as well as the species in more than five sites. In Figure 4 can be observed that at higher levels of total solar radiation in burned areas, Muhlenbergia quadridentata $\bigcirc$. (Kunth) Trin. increased its density, which highlights its intolerance to shadow. Similar results were obtained for direct solar radiation ( $\left.\mathrm{p}=0.0385, \mathrm{R}^{2}=0.6085\right)$ and diffuse $(\mathrm{p}=0.04484$, $R^{2}=0.5861$ ). Rzedowski ( 1981) underlines that fire is a major factor for the existence and dynamics of grasslands with species such as M. quadridentata. Penstemon gentianoides is typical of burned areas; however, in the actual work, their dominance lowers as radiation increases (Figure 5). A similar relation was observed in regard to diffuse solar radiation $\left(\mathrm{p}=0.00124, \mathrm{R}^{2}=0.6638\right)$, which might be linked to the available moisture. Schroeder and Buck (1970), as well as Arnaldos et al. (2004), confirmed that the in the northern hemisphere, the NW hillsides are slightly more humid than those exposed at the west, since there is a moisture gradient from 
Lupinus montanus y Penstemon gentianoides han sido señaladas como indicadoras de áreas incendiadas (Rzedowski, 1978; Rodríguez y Sierra, 1992; García, 2004; Espinoza et al., 2008; Martínez y Rodríguez, 2008). La semilla de Lupinus tiene latencia física; por lo que el calor del fuego actúa como un agente natural de escarificación que debilita la cubierta seminal de simientes enterradas someramente en el piso forestal, lo cual favorece la germinación. Las semillas muy enterradas no reciben suficiente calor, y aquéllas que están sobre la superficie resultan quemadas (Acosta y Rodríguez, 2005; Martínez et al., 2008).

Como en este caso, Armour et al. (1984) refieren especies indicadoras de áreas incendiadas en bosques de Pinus ponderosa, incluso para diferentes intensidades de fuego: Berberis repens Lindl. estuvo ausente en sitios de alta intensidad; Luzula campestris (L.) DC. fue siete veces más frecuente en espacios no siniestrados, que en los quemados a alta intensidad; Fragaria virginiana Mill. se presentó el doble de ocasiones en zonas sin fuego y quemadas a baja intensidad, en comparación con los de alta intensidad; Potentilla gracilis Douglas ex Hook., Geum triflorum Pursh. y Vicia americana Muhl. ex Willd. fueron más comunes en áreas de baja intensidad que en las otras; Ceanothus sanguineus Pursh. y Apocynum androsaemifolium L. solo se registraron en sitios de alta intensidad; Epilobium angustifolium L. fue de dos a cinco veces más frecuente en espacios de alta intensidad que en los de baja y extremadamente rara en zonas no quemadas; Collomia linearis Nutt. se localizó en áreas incendiadas y no quemadas, pero fue más común en aquellas de alta intensidad.

\section{Efectos de la radiación solar}

De todas las especies herbáceas identificadas en las parcelas con quema prescrita, solo tres mostraron tendencias significativas. Se consideraron las regresiones con $\mathrm{R}^{2}>0.4$ y con $\mathrm{p}<0.10$, así como la presencia de la especie en más de cinco sitios. En la Figura 4 se aprecia que a mayores niveles de radiación solar total en las áreas quemadas, Muhlenbergia quadridentata $\mathrm{O}$. (Kunth) Trin. incrementa su densidad, lo cual destaca su intolerancia a la sombra. Resultados similares se obtuvieron para la ra diación solar directa ( $p=0.0385$, $R^{2}=0.6085$ ) y para la difusa ( $\left.p=0.04484, R^{2}=0.5861\right)$. Rzedowski (1981) subraya que el fuego es un factor importante en la existencia y dinámica de pastizales con especies como M. quadridentata. Penstemon gentianoides es típica de áreas incendiadas, sin embargo, en el presente trabajo su dominancia se reduce al incrementar la radiación (Figura 5). Una relación semejante se observó con respecto a la radiación solar difusa ( $\mathrm{p}=0.00124, \mathrm{R}^{2}=0.6638$ ), la cual puede estar vinculada con la humedad disponible. Schroeder y Buck (1970), así como Arnaldos et al. (2004) consignan que en el hemisferio norte las laderas con exposición $\mathrm{NO}$ son ligeramente más húmedas que las expuestas en el oeste, pues hay un gradiente de humedad de menor a mayor que parte de las exposiciones $\mathrm{SO}$, las más secas, hacia las $\mathrm{O}, \mathrm{NO}, \mathrm{N}$ y $\mathrm{NE}$. smallest to largest that starts from the SW exposures, the drier towards W, NW, N and NE.

Cuadro 7. Valores de significancia para especies herbáceas en el área de quema (prueba de $\chi^{2}$.

Table 7. Significance values for herb species in the burned area $\left(\chi^{2}\right.$ test).

\begin{tabular}{lc}
\hline Especie & Significancia \\
\hline Calamagrostis tolucensis* (Kunth) Trin. Ex Steud. & 0.0001 \\
Festuca tolucensis * Kunth & 0.0001 \\
Muhlenbergia quadridentata* O. (Kunth) Trin. & 0.0001 \\
Penstemon gentianoides (Kunth)Poir. & 0.0001 \\
Selloa plantaginea Kunth & 0.0001 \\
Senecio angulifolius ${ }^{*}$ DC. & 0.0001 \\
Senecio reticulatus * DC. & 0.0001 \\
Salvia prunelloides * Kunth & 0.0017 \\
Senecio callosus Sch. Bip. & 0.0052 \\
Pernettya ciliata * Small & 0.0065 \\
Gnaphalium sphacelatum * Kunth & 0.0077 \\
\hline
\end{tabular}

Cuadro 8. Valores de significancia para especies arbustivas en el área de quema (prueba de $\chi^{2}$ ).

Table 8. Significance values for shrub species in the burned area $\left(\chi^{2}\right.$ test).

\begin{tabular}{lc}
\hline Especie & Significancia \\
\hline Lupinus montanus Kunth & 0.0001 \\
Senecio cineraroides Kunth & 0.0001 \\
Baccharis conferta ${ }^{*}$ Kunth & 0.0956 \\
\hline
\end{tabular}

A great density and dominance of $M$. quadridentata was observed after one or two years from the prescribed burnings in areas almost devoid of trees in a different site of Ajusco volcano which is located at a higher altitude and on a NW hillside, slightly more humid than that of the W of the actual work, in a hillside curved inside and with a steeper slope that allow a greater seed accumulation (carried by superficial runoffs), and moisture, as well as a lower radiation income that helps to keep such moisture (Espinoza et al., 2008; Martínez and Rodríguez, 2008).

García (2004) pointed out that $P$. gentianoides is more abundant over moist hillsides, such as inside rifts, where it forms dense brushes. The same author documented that 12 to 24 months after fires, P. gentianoides becomes dominant, while after 18 to 36 months, Lupinus montanus does.

This species was very abundant during the first year in the experimental areas of the NW hillside of Ajusco (Martínez and 


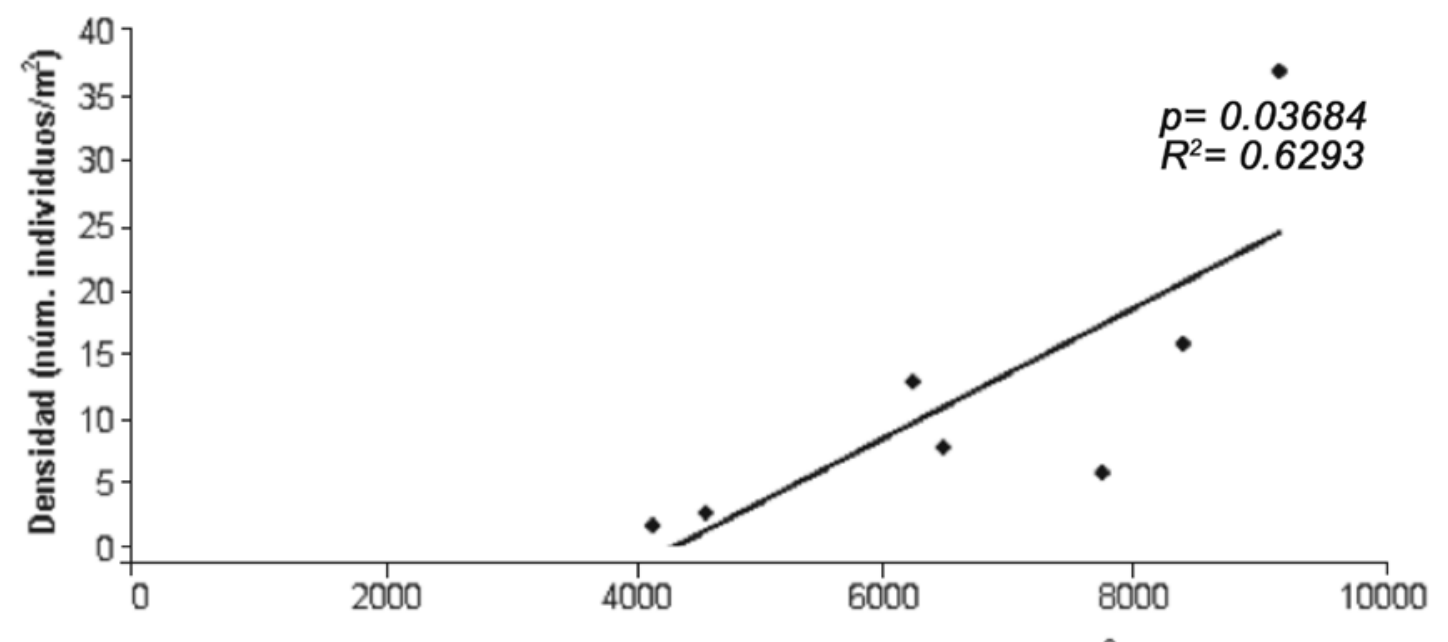

\section{Radiación solar total por debajo del dosel ( $\left.\mathrm{mJ} / \mathrm{m}^{2} / a n ̃ o\right)$}

Figura 4. Relación directa entre la densidad de Muhlenbergia quadridentata $\bigcirc$. (Kunth) Trin. y el nivel de radiación solar total por debajo del dosel.

Figure 4. Direct relation between Muhlenbergia quadridentata $\bigcirc$. (Kunth) Trin. density and the total solar radiation below the canopy.

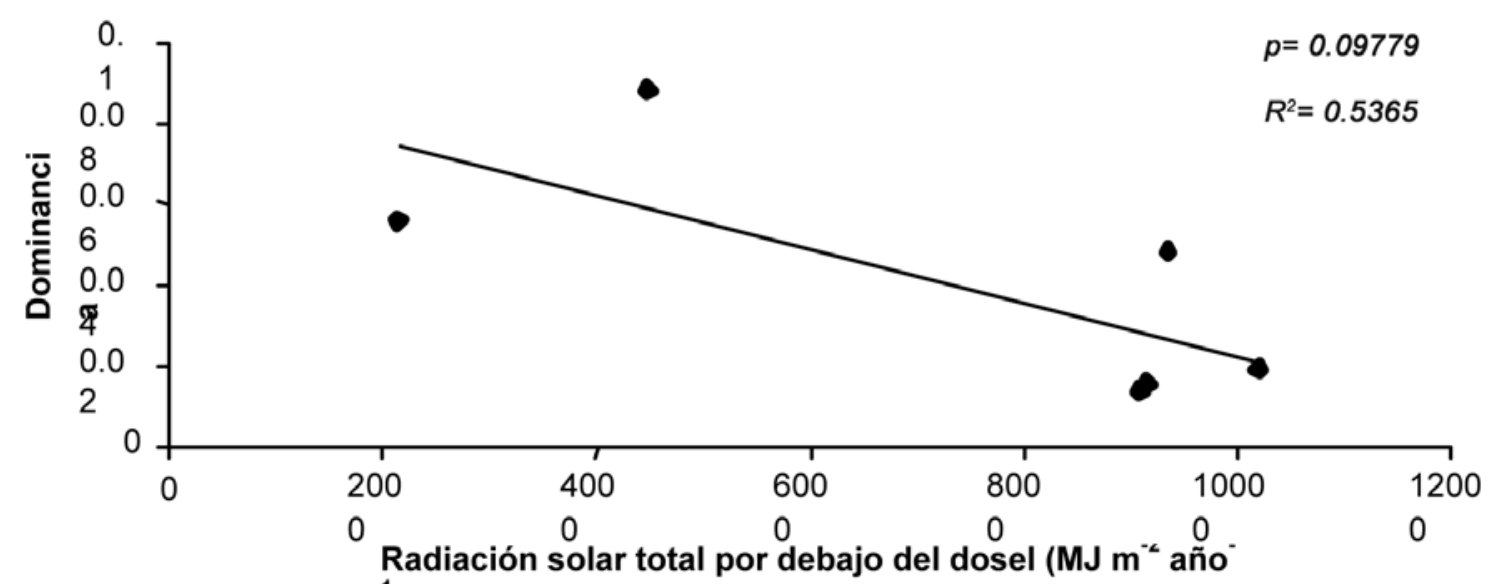

Figura 5. Respuesta en dominancia de Penstemon gentianoides (Kunth) Poir. a la porción de cielo visible en sitios con quema prescrita.

Figure 5. Dominance reponse of Penstemon gentianoides (Kunth) Poir. to the visible sky portion in prescribed burning sites.

Una gran densidad y dominancia de M. quadridentata se observó después de uno y dos años de la quema prescrita en áreas casi sin arbolado en otro sitio del volcán Ajusco, el cual se ubica a una mayor altitud y sobre una exposición $\mathrm{NO}$, ligeramente más húmeda que la $\bigcirc$ del presente trabajo, y en una ladera cóncava y con pendiente más acentuada que permiten una mayor acumulación de semillas lacarreadas por los escurrimientos superficiales) y humedad, además de, menor incidencia de radiación que ayuda a mantener dicha humedad (Espinoza et al., 2008; Martínez y Rodríguez, 2008).
Rodríguez, 2008). In a similar way, in a subalpine forest burned in Patagonia, lower soil moisture and seedling survival were obtained at higher radiation levels (Kitzberger et al., 2005).

Senecio reticulatus showed a reduction in its dominance before higher radiation levels that might be related to greater moisture demands of the species (Figure 6). The tendency was similar for the same variable, in regard to direct solar radiation $\left(p=0.09336, R^{2}=0.546\right)$. Two of the shrubs registered in the burned area showed significance when they were related to the indicators 
García (2004) señala que P. gentianoides es más abundante sobre laderas húmedas, como los interiores de barrancos, donde forma matorrales densos. El mismo autor documenta que de 12 a 24 meses después de los incendios, P. gentianoides es dominante, mientras que de los 18 a los 36 meses, lo hace Lupinus montanus domina. Esta especie fue muy abundante el primer año en las áreas experimentales de la ladera NO del Aiusco (Martínez y Rodríguez, 2008). De manera similar en un bosque subalpino incendiado en la Patagonia se obtuvieron menor humedad del suelo y supervivencia de plántulas a mayores niveles de radiación (Kitzberger et al., 2005).

Senecio reticulatus mostró una reducción en su dominancia ante niveles más altos de radiación, que pueden relacionarse con mayores requerimientos de humedad de la especie (Figura 6). La tendencia fue parecida para la misma variable, con respecto a la radiación solar directa ( $\mathrm{p}=0.09336, \mathrm{R}^{2}=0.546$ ). En el caso de las arbustivas registradas en el área de la quema, dos presentaron significancia al relacionarlas con los indicadores de los diferentes niveles de radiación solar. Cirsium ehrenbergii Sch. Bip. aumentó su dominancia y densidad ( $p=0.07806, R^{2}=0.5114$ ) cuando la proporción de cielo visible aumentó (Figura 7).

Eryngium monocephalum Cav. incrementó su densidad a menores niveles de radiación: radiación solar total debajo del dosel, $p=0.01168, R^{2}=0.9105$; radiación solar directa, $p=0.00975, R^{2}=0.9205$; radiación solar difusa, $\mathrm{p}=0.06764, \mathrm{R}^{2}=07238$. Lo anterior posiblemente también se relacione con un requerimiento superior de humedad, la cual se mantiene mejor bajo la sombra parcial de las copas de los árboles. of the different levels of solar radiation Cirsium ehrenbergii Sch. Bip. increased its dominance and density $\left(p=0.07806, R^{2}=0.5114\right)$ as the proportion of visible sky increased (Figure 7).

Eryngium monocephalum Cav. increased its density at lower radiation levels: total solar radiation below the canopy, $\mathrm{p}=0.01168$, $\mathrm{R}^{2}=0.9105$; direct solar radiation, $\mathrm{p}=0.00975, \mathrm{R}^{2}=0.9205$; diffuse solar radiation, $p=0.06764, R^{2}=0.7238$. This might be related as well, to a higher moisture demand, which keeps better under the partial shadow of the tree crowns.

The taxa that were located in the control area in the herb stratum as well as in the shrub one did not show any significance in regard to the radiation levels that were studied, which correlated with the total number of specie for each one of the treatments. The shrub species of the non-burned area were the only ones that displayed a tendency that indicates the existence of a larger number of shrub species with less total $\left(p=0.02096, R^{2}=0.43\right)$ and direct solar radiation $\left(\mathrm{p}=0.02018, \mathrm{R}^{2}=0.4324\right)$ below the canopy, even though until de second year, shrubs reached a more prominent presence (Espinoza et al., 2008).

More species with tendencies linked to radiation were expected; however, many did not show that condition, which might be claimed to the fact that this research refers to the first year in which shrubs, in particular, are just emerging. On the other hand, the coniunction of other factors such as moisture, documented for Penstemon gentianoides, might imply different tendencies; for example, in a study made over Fagus sylvatica L. masses in Hainich National Park at Thüringen, Germany, there was no relation between the canopy cover and the diversity of species of the

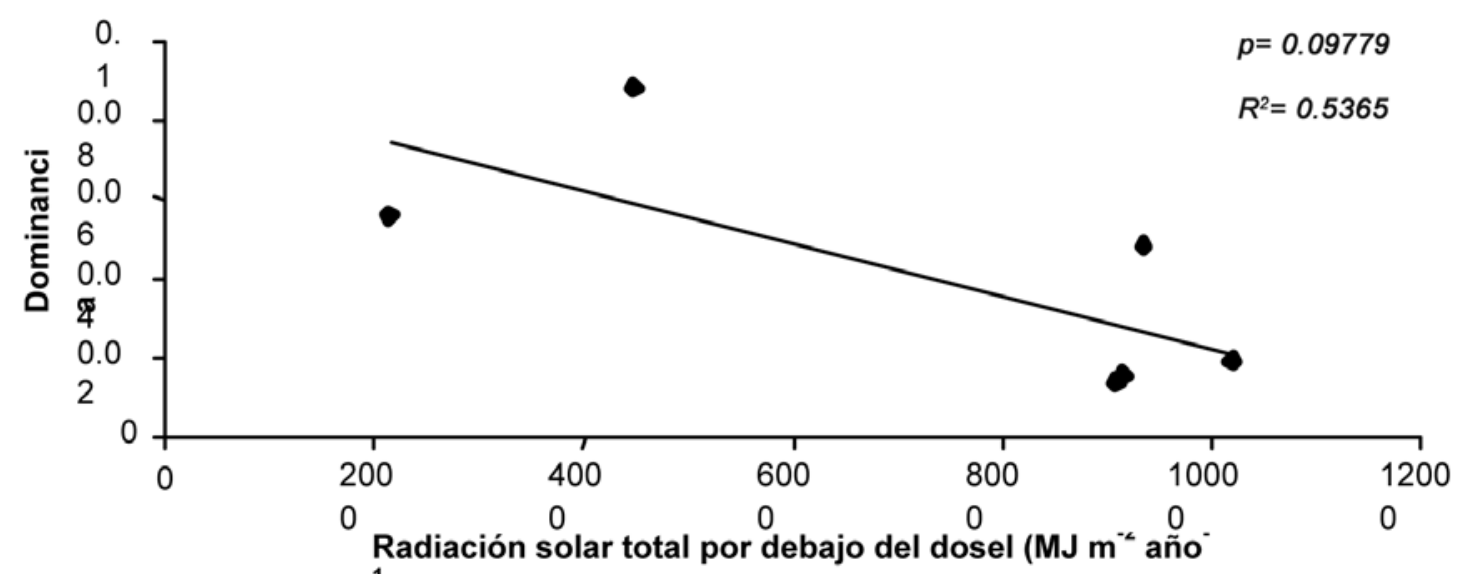

Figura 6. Dominancia de Senecio reticulatus DC. en relación al nivel de radiación solar total. Figure 6. Senecio reticulatus DC dominance in regard to the total radiation level. 


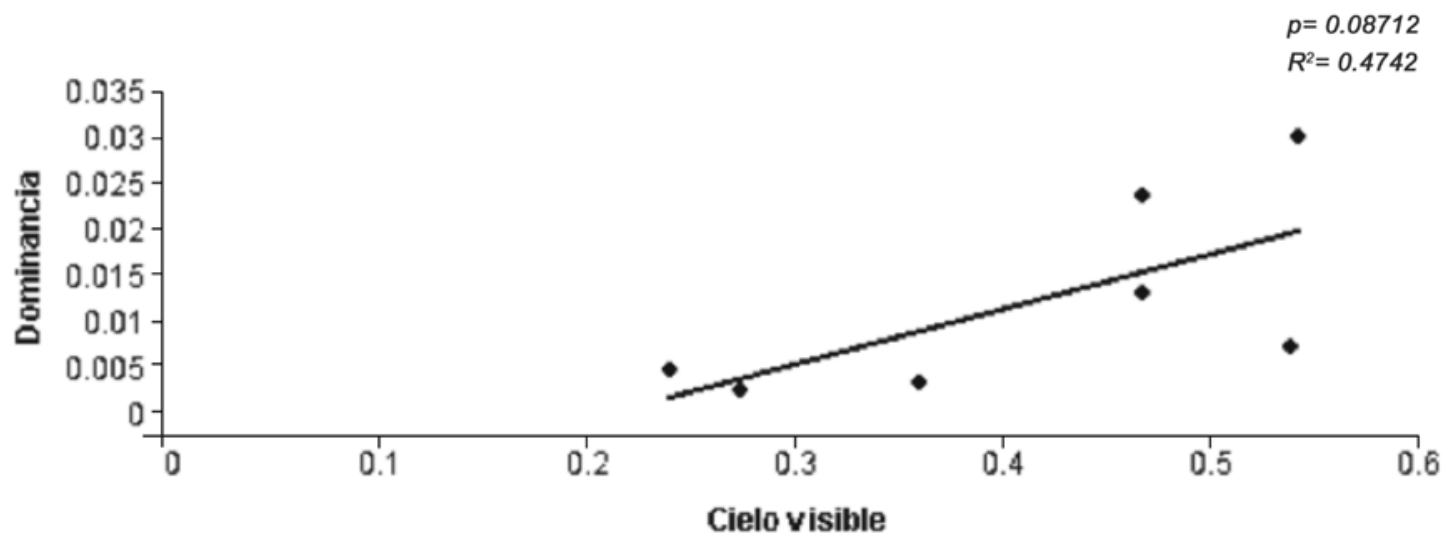

Figura 7. Dominancia de Cirsium ehrenbergii Sch. Bip. relativa a la porción de cielo visible.

Figure 7. Cirsium ehrenbergii Sch. Bip. dominance related to the visible sky portion.

En cuanto a los taxa localizados en el área testigo tanto del estrato herbáceo, como del arbustivo no presentaron significancia en relación con los niveles de radiación estudiados, los cuales se correlacionaron con el número total de especies para cada uno de los tratamientos. Las especies arbustivas del área no quemada fueron las únicas que confirmaron una tendencia que indica la existencia de un número más grande de especies arbustivas con menor radiación solar total ( $\mathrm{p}=0.02096, \mathrm{R}^{2}=0.43$ ) y directa ( $\mathrm{p}=0.02018, \mathrm{R}^{2}=0.4324$ ) por debajo del dosel, si bien, hasta el segundo año los arbustos alcanzaron una presencia mayor (Espinoza et al., 2008).

Se esperaban más especies con tendencias vinculadas a la radiación; sin embargo, muchas no evidenciaron tal característica, lo cual puede aducirse a que la investigación corresponde a un primer año, en el que, en particular, las arbustivas aún son incipientes. Por otro lado, el concurso de otros factores como los requerimientos de humedad, documentado para Penstemon gentianoides, pueden implicar tendencias distintas; por ejemplo, en un estudio efectuado dentro del Parque Nacional Hainich, Turingia, Alemania, con masas de Fagus sylvatica L. no existió relación entre la cobertura de dosel y la diversidad de especies del sotobosque; aunque esta última sí se asoció con el pH del suelo (Mölder et al., 2008). Además, es relevante considerar que la importancia de los factores limitativos varía entre años: las plántulas de $P$. strobus $L$. en Norteamérica durante un año tuvieron al nitrógeno como principal recurso limitativo; no obstante, al año siguiente resultó más importante la radiación (Elliott y Vose, 1995).

Los intervalos de radiación manejados en este trabajo no son tan amplios, lo que facilita la plasticidad ante distintos niveles de radiación al sotobosque, pues comúnmente las masas de Pinus hartwegii son más o menos abiertas. En promedio, la radiación solar total fue de $6700 \mathrm{MJ} \mathrm{m}^{-2}$ año ${ }^{-1}$ en las áreas quemadas, mientras que undergrowth, even though the latter did associate with the $\mathrm{pH}$ of the soil (Mölder et al., 2008). It is also relevant to consider that the importance of the limiting factors varies among years: P. strobus L. seedlings in North America during one year had nitrogen as the main limiting factor, but next year, radiation was even more important (Elliott and Vose, 1995).

The radiation intervals considered in this paper are not so wide, which favors the plasticity at the face of different levels of radiations to the belowgrowth, as regularly the masses of Pinus hartwegii are more or less open. On average, the total solar radiation was of $6700 \mathrm{MJ} \mathrm{m}^{-2}$ año-1 in the burned areas, while Mendoza et al. (2011) indicate value of $2794 \mathrm{MJ} \mathrm{m}^{-2}$ año-1 in locations by Quercus laurina Humb. et Bonpl.

\section{CONCLUSIONS}

After a year of having applied prescribed burnings, the below canopy direct, diffuse and total solar radiation values returned to their original records. The visual sky portion even was a little bigger in the treated areas.

The application of low intensity prescribed burnings in the Pinus hartwegii forest doubled species richness in the herb and shrub strata without causing significant mortality of the trees.

Nine species were included as typical of burned areas for the first time.

The greatest available radiation a little after the application of fire was not the only factor that favored diversity. The abatement of the aerial part of Graminae, which lowered its importance value from 58 to $30 \%$ in not-burned areas, after a year from 
Mendoza et al. (2011) señalan valores de $2794 \mathrm{MJ} \mathrm{m}^{-2}$ año-1 en localidades dominadas por Quercus laurina Humb. et Bonpl.

\section{CONCLUSIONES}

Después de un año de haberse aplicado las quemas prescritas, los valores de radiación solar directa, difusa y total bajo dosel retornaron a sus niveles originales. La porción de cielo visible aún era un poco mayor en las áreas tratadas.

La aplicación de quemas prescritas a baja intensidad en el bosque de Pinus hartwegii duplicó la riqueza de especies de los estratos herbáceo y arbustivo sin causar mortalidad significativa en el arbolado.

Nueve especies se incluyen por primera vez como típicas de áreas quemadas.

La mayor radiación disponible poco después de la aplicación del fuego, no fue el único factor que propició la diversidad. El abatimiento de la parte aérea de gramíneas, cuyo valor de importancia descendió de 58 a 30\% en áreas no quemadas, al año de la aplicación de las quemas prescritas, redujo la competencia y permitió una mayor disponibilidad de recursos de crecimiento que favoreció la proliferación de otras especies.

En las parcelas tratadas con fuego, Muhlenbergia quadridentata y Cirsium ehrenbergii incrementaron su densidad o dominancia a mayores niveles de radiación; en contraste, Senecio reticulatus, Eryngium monocephalus y Penstemon gentianoides disminuyeron al incrementarse la radiación.

El hecho de no obtener tendencias en otras especies más comunes indica plasticidad de las mismas ante los niveles de radiación estudiados; en consecuencia, quedan pendientes investigaciones que incluyan mayores niveles de sombra; así como estudios cuantitativos de ecología del fuego y otros que demuestren los requerimientos de luz de diversas especies de sotobosque, las cuales, a pesar de responder bien en ambientes quemados, pueden ser más plásticas en términos de sus necesidades de luz de lo que se cree.

\section{AGRADECIMIENTOS}

A las Comunidades de San Miguel y de Santo Tomás Ajusco, por permitir el establecimiento y desarrollo de proyecto Ajusco en sus tierras. Al gobierno de la ciudad de México y a la Comisión Nacional Forestal, por la autorización y ayuda para efectuar las quemas prescritas. A la Universidad Autónoma Chapingo, al Consejo Nacional de Ciencia y Tecnología y al Fondo Mexicano para la Conservación de la Naturaleza, por el soporte financiero para llevar a cabo el presente estudio. Al herbario del Departamento de Zootecnia de la Universidad Autónoma Chapingo, por el apoyo en la identificación de especies y al Sr. Gerardo Mendoza Ángeles, por su colaboración en el trabajo de campo. Esta investigación forma parte del Proyecto Ajusco de la Universidad Autónoma Chapingo sobre ecología del fuego, manejo integral de incendios forestales y restauración de áreas incendiadas, iniciado en el año 2000 the application of prescribed burnings, reduced competition and allowed a greater availability of growth resources that favored the outburst of other species.

In fire treated plots, Muhlenbergia quadridentata and Cirsium ehrenbergii rose their density or dominance from higher radiation levels; in contrast, Senecio reticulatus, Eryngium monocephalus and Penstemon gentianoides diminished as radiation increased.

The fact of not having found tendencies in other more common species indicates their plasticity in the face of the radiation levels studied here; consequently, research is still to be done which could include more intense shadow levels, as well as quantitative studies about fire ecology, and others that demonstrate the light requirements of several undergrowth species, which, in spite of showing a good response to burned environments, might be more plastic in terms of light demands to what is believed.

\section{ACKNOWLEDGEMENTS}

To the San Miguel and Santo Tomás Aiusco Communities for allowing the establishment and development of the Aiusco project in their lands. to the government of Mexico City and to the Comisión Nacional Forestal, for their authorization and help to carry on the prescribed burnings. To the Universidad Autónoma Chapingo, to the Consejo Nacional de Ciencia y Tecnología and to the Fondo Mexicano para la Conservación de la Naturaleza for the financial support they provided in order to accomplish the actual study. To the Zootechny Department herbarium of the Universidad Autónoma Chapingo, as they helped in the determination of botanic species and to Mr. Gerardo Mendoza Ángeles, for his help in field work. This study is part of the Ajusco Project of the Universidad Autónoma Chapingo about fire ecology, forest fire management and restoration of burned areas, which was started in 2000.

End of the English version

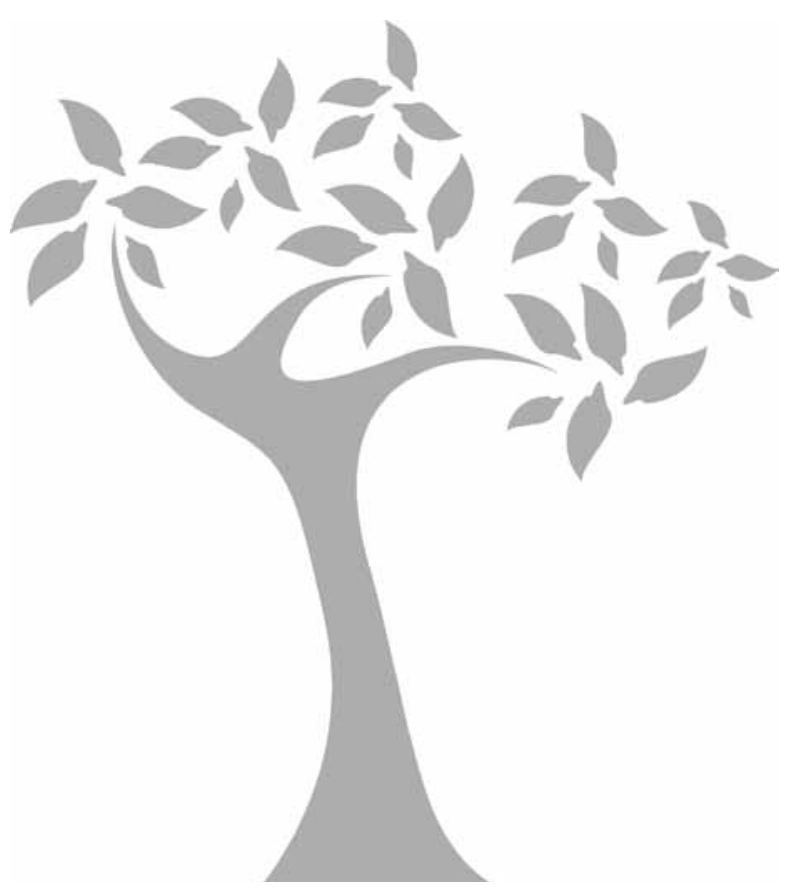




\section{REFERENCIAS}

Acosta P., J. and D. A. Rodríguez T. 2005. Factors affecting germination and pregerminative treatments of Lupinus montanus seeds. Interciencia 30 (9): 1-4.

Agee, J. K. 1993. Fire ecology of Pacific Northwest Forests. Island Press. Washington, DC. USA. $493 \mathrm{p}$

Armour, C. D., S. C. Bunting and F. L. Neuenschwander. 1984. Fire intensity effects on the understory in ponderosa pine forest. Journal of Range Management. 37(1): 44-49.

Arnaldos V., J., X. Navalón N., E. Pastor F., E. Planas C. y L. Zárate L. 2004. Manual de ingeniería básica para la prevención y extinción de incendios forestales. Mundi-Prensa. Madrid, España. 414 p.

Benítez B., G. 1986. Árboles y flores del Ajusco. Instituto de Ecología. Museo de Historia Natural de la Ciudad de México. México, D. F. México. $183 p$

Benítez B., G. 1987. Efecto del fuego en la vegetación herbácea de un bosque de Pinus hartwegii Lindl. en la Sierra del Ajusco. In: Rapoport, E. H. e I. R. López M. (eds.). Aportes a la ecología urbana de la ciudad de México. Limusa. México, D. F. México. pp. 111-152.

Brockway, D. G. and C. E. Lewis. 1997. Long-term effects of dormant-season prescribed fire on plant community diversity, structure and productivity in a longleaf pine wire grass ecosystem. Forest Ecology and Management. 96 (1-2): 167-183.

Comisión Nacional Forestal (Conafor). 2009. Reporte de incendios forestales. http://www.conafor.gob.mx/portal/. (30 de noviembre de 2009).

Elliott, K. J. and J. M. Vose. 1995. Evaluation of the competitive environment for white pine (Pinus strobes L.) seedlings planted on prescribed burn sites in the southern Appalachians. Forest Science 41 (3):513-530.

Espinoza M., L. A., D. A. Rodríguez T. y F. J. Zamudio S. 2008. Sinecología del sotobosque de Pinus hartwegii dos y tres años después de quemas prescritas. Agrociencia. 42:717-730

García, E. 1973. Modificaciones al sistema de clasificación climática de Köppen (para adaptarlo a las condiciones de la República Mexicana). Universidad Nacional Autónoma de México. Instituto de Geografía. México, D. F. México. 252 p.

García R., A. 2004. Dinámica del paisaje post-fuego en el pastizal tropical de alta montaña. Volcán Iztaccihualt. México. Interciencia. 29 ( 11 ):604-611.

Gobierno de la ciudad de México. 2009. Reporte de incendios forestales. http:// wwwsma.dfgob.mx/corena/conservacion/proteccion_noła_diariaphp. (30 de noviembre de 2009).

Kitzberger, T., E. Raffaele, K. Heinemann and M. J. Mazzarino. 2005. Efects of fire severity in a north Patagonian subalpine forest. Journal of Vegetation Science 16 (1):5-12.

Krebs, C. J. 1985. Ecología: estudio de la distribución y abundancia. Ed. Harla. México, DF. México. $743 \mathrm{p}$.

Lambers, H., F. S. Chapin III and T. L. Pons. 1998. Plant physiological ecology. Springer. New York, NY USA. 540 p.

Martínez H., H. C. and D. A. Rodríguez T. 2008. Species diversity after prescribed burns at different intensities and seasons in a high altitude Pinus hartwegii forest. Interciencia. 33 (5):337-344.

Martínez J., M., D. A. Rodríguez T. y E. Guizar N. 2008 Escarificación artificial y natural de la semilla de Lupinus bilineatus Benth. Revista Chapingo, Serie Ciencias Forestales y del Ambiente. 14 (2):73-79.
Mendoza B., C., F. García M., D. A. Rodríguez T. y S. Castro Z. 2011. Radiación solar y calidad de planta en una plantación de vara de perlilla (Symphoricarpos microphyllus H.B.K.). Agrociencia 45 (2):235-243.

Mölder, A., M. Bernhardt-Römermann and W. Schmidt. 2008. Herb-layer diversity in deciduous forests: Raised by tree richness or beaten by beech? Forest Ecology and Management. 256 (3):272-281.

Perry Jr., J. P. 1991. The pines of Mexico and Central America. Timber Press. Portland, OR. USA. $231 \mathrm{p}$.

Rodríguez T., D. A. 1996. Incendios Forestales. Universidad Autónoma ChapingoMundi-Prensa. México, D.F. México. 630 p.

Rodríguez T., D. A. 2001. La ecología del fuego en el pinar de Pinus hartwegii. Revista Chapingo. Serie Ciencias Forestales y del Ambiente. 7 (2): 145-151.

Rodríguez T., D. A. y A. Sierra P. 1992. Bosquejo histórico sobre diversos aspectos de los incendios forestales en México. Ciencia Forestal en México 17(72): 115- 174

Rodríguez T., D. A. and P. Z. Fulé. 2003. Fire ecology of Mexican pines and a fire management proposal. International Journal of Wildland Fire. 12 (1):23-37

Rodríguez T., D. A., H. C. Martínez H. y V Ortega B. 2004. Ecología del fuego en bosques de Pinus hartwegii. In: Villers L., R. y J. López B. (eds.). Incendios Forestales en México. Métodos de evaluación. UNAM. México, D. F. México. pp 107-124.

Rothermel, R. C. 1983. How to predict the spread and intensity of forest fires and range forest fires. USDA Forest Service. Gen. Tech. Rep. INT- 143. Ogden, UT. USA. $161 \mathrm{p}$.

Rzedowski, J. 1978. Vegetación de México. Limusa. México, D. F. México. 432p.

Rzedowski, J. 1981. Comunidades vegetales. In: Rzedowski, J. y G. C. de Rzedowski. (eds.). Flora fanerogámica del Valle de México. Vol. I. CECSA. México, D. F. México. pp. 48-60.

Schroeder, M. J. and C. C. Buck. 1970. Fire weather. Agriculture Handbook 360. USDA Forest Service. Washington, DC. USA. 229 p.

Shlisky, A., J. Waugh, P. González, M. González, M. Manta, H. Santoso, E. Alvarado, A. A. Nuruddin, D. A. Rodríguez T., R Swaty, D. Schmidt, M. Kauffman, R. Myers, A. Alencar, F. Kearns, D. Johnson, J. Smith, D. Zollner y W. Fulks. 2007. El fuego, los ecosistemas y la gente. Amenazas y estrategias para la conservación global de la biodiversidad. The Nature Conservancy. Arlington, VA. USA. $20 \mathrm{p}$

Spencer, R. J. and G. S. Baxter. 2006. Effects of prescribed fire and fire history on the structure and composition of mixed forests on Fraser Island, Australia. Austral Ecology. 31:638-646.

Statistical Analysis System (SAS). 1999. SAS Institute (version 8.0). Cary, NC. USA. s/p. Wade, D. D., B. L. Brosk, P. H. Brose, J. B. Grace, G. A. Hotch. and W. A. Patterson. 2000. Fire in eastern ecosystems. In: Brown, J. K. and J. Kapler-Smith (Eds.). Wildland fire in ecosystems. Effects of fire on flora. USDA Forest Service. Gen. Tech. Rep. RMRS-GTR 42. Ogen, UT. USA. 2: 53-96.

Whelan, R. H. 1997. The ecology of fire. Cambridge University Press. Cambridge, UK. 346p.

Wright, H. A. and A. W. Bailey. 1982. Fire ecology: United States and Southern Canada. John Wiley and Sons. New York, NY. USA. 501 p. 